\title{
The Modular Organization of Projections from Areas V1 and V2 to Areas V4 and TEO in Macaques
}

\author{
Hiroyuki Nakamura, ${ }^{\mathrm{a}}$ Ricardo Gattass, ${ }^{\mathrm{b}}$ Robert Desimone, and Leslie G. Ungerleider \\ Laboratory of Neuropsychology, National Institute of Mental Health, Bethesda, Maryland 20892
}

In addition to the major anatomical pathways from $V_{1}$ into the temporal lobe, there are other smaller, "bypass" routes that are poorly understood. To investigate the direct projection from V1 to V4 (bypassing V2) and from V2 to TEO (bypassing V4), we injected the foveal and parafoveal representations of V4 and TEO with different retrograde tracers in five hemispheres of four macaques and analyzed the distributions of labeled neurons in $V_{1}$ and $V_{2}$ using flattened preparations of the cortex. In V1, labeled neurons were seen after injections in V4 but not TEO. The V4-projecting neurons were located in the foveal representation of $\mathrm{V} 1$, in both cytochrome oxidase (CO)-rich blobs and $\mathrm{CO}$-poor interblob regions. In V2, TEO-projecting neurons were intermingled with V4-projecting neurons, although the former were far sparser than the latter. Across the cases, 6-19\% of the TEOprojecting neurons were double labeled, that is, also projected to area V4. Both V4- and TEO-projecting neurons formed bands that ran orthogonal to the $V_{1} / V_{2}$ border, and both were located in CO-rich thin stripes and CO-poor interstripe regions. In some cases, a continuous band of V4projecting neurons was also found along the $V_{1} / V_{2}$ border in the foveal representation of V2. The results indicate that the pathways from $V_{1}$ to $V_{4}$ and from $V_{2}$ to TEO involve anatomical subcompartments thought to be concerned with both color and form. These "bypass" routes may allow coarse information about color and form to arrive rapidly in the temporal lobe. The bypass route from V2 to TEO might explain the partial sparing of color and form vision that is seen after lesions of V4. By analogy, given the bypass route from the foveal representation of $V_{1}$ to $V_{4}$, lesions of $V_{2}$ affecting the foveal visual field would also be insufficient to block color and form vision.

IKey words: visual cortex, extrastriate cortex, striate cortex, occipitotemporal pathway, object recognition, color vision, form vision, monkey]

\footnotetext{
Received Nov. 18, 1992; revised Feb. 24, 1993; accepted Mar. 3, 1993.

We thank Dr. Mortimer Mishkin for his advice and support throughout the study and for his comments on the manuscript. We also thank Michelle Adams, Thelma W. Galkin, Joanna Lawrence, John N. Sewell III, and John Ward for skillful technical assistance.

Correspondence should be addressed to Dr. Leslie G. Ungerleider, Laboratory of Neuropsychology, NIMH, Building 49, Room 1B80, Bethesda, MD 20892.

aPresent address: Department of Anatomy, Faculty of Medicine, Kyushu University, Fukuoka 812, Japan.

Present address: Departamento de Neurobiologia, Instituto de Biofisica Carlos Chagas Filho, Universidade Federal do Rio de Janeiro, 21941 Rio de Janeiro, RJ, Brazil.

Copyright (C) 1993 Society for Neuroscience $0270-6474 / 93 / 133681-11 \$ 05.00 / 0$
}

The occipitotemporal pathway underlying object recognition in primates extends from $\mathrm{V} 1$ to area TE within inferior temporal cortex, via projections through areas V2, V4, and TEO (for reviews, see Ungerleider and Mishkin, 1982; Mishkin et al., 1983; Ungerleider, 1985; Maunsell and Newsome, 1987; Weller, 1988; Desimone and Ungerleider, 1989; Felleman and Van Essen, 1991; Van Essen et al., 1991, 1992). Within at least the early stations of this pathway, there are known to be functional modules with differential contributions to color, form, and motion processing. In V1 and V2, modules can be identified histologically in cytochrome oxidase (CO)-stained sections (Horton and Hubel, 1981; Livingstone and Hubel, 1982, 1984; Humphrey and Hendrickson, 1983; Tootell et al., 1983; Carroll and Wong-Riley, 1984; Horton 1984; Wong-Riley and Carroll, 1984; DeYoe and Van Essen, 1985; Hubel and Livingstone, 1985, 1987; Shipp and Zeki, 1985, 1989; Cusick and Kaas, 1988; Zeki and Shipp, 1989; Gattass et al., 1990; Krubitzer and Kaas, 1990). In V1, there are CO-rich blobs in layers 2, 3, 5, and 6, which are surrounded by $\mathrm{CO}$-poor interblob regions (Horton and Hubel, 1981; Livingstone and Hubel, 1982, 1984; Humphrey and Hendrickson, 1983; Carroll and Wong-Riley, 1984; Horton, 1984; Cusick and Kaas, 1988; Rosa et al., 1988, 1991; Krubitzer and Kaas, 1990). Although both blob and interblob regions in layers 2 and 3 receive their predominant input indirectly from the parvocellular layers of the $\mathrm{LGN}$ via layer IVC $\beta$ (Hubel and Wiesel, 1972; Lund, 1973; Lund and Boothe, 1975; Hendrickson et al., 1978; Blasdel and Lund, 1983; Fitzpatrick et al., 1985), neurons in the blobs tend to have less orientation selectivity, lower spatial frequency tuning, and greater sensitivity to color than cells in the interblob regions (Livingstone and Hubel, 1984; Tootell et al., 1988a,c; Ts'o and Gilbert, 1988; but see Lennie et al., 1990). It should be pointed out, however, that the functional significance of the blobs is still a matter of debate, given that the blobs also receive indirect magnocellular input from the LGN via layer IVC $\alpha$ (Lachica et al., 1992) and are found in nocturnal primates with poor color vision (Condo and Casagrande, 1990). Indeed, Allman and Zucker (1990) have proposcd that stimulus intensity is represented in the blobs rather than color per se, whereas stimulus geometry is represented in the interblobs. Outside of the blob/interblob system in $\mathrm{V} 1$, neurons in layer $4 \mathrm{~B}$ receive their predominant input indirectly from the magnocellular layers of the LGN via layer IVC $\alpha$ (Hubel and Wiesel, 1972; Lund, 1973; Lund and Boothe, 1975; Blasdel and Lund, 1983; Blasdel et al., 1985) and tend to have high contrast and directional selectivity (Tootell et al., 1988b). 
Area V2 has both thick and thin stripes of dense CO staining situated in deep layer 3 and layers 4 and 5, each bordered by CO-poor interstripe regions (Tootell et al., 1983; Livingstone and Hubel, 1984, 1987; DeYoe and Van Essen, 1985; Hubel and Livingstone, 1985, 1987; Shipp and Zeki, 1985, 1989; Cusick and Kaas, 1988; Zeki and Shipp, 1989; Gattass et al., 1990; Krubitzer and Kaas, 1990). The CO-rich thin stripes of V2 reccive inputs from the blobs of $\mathrm{V} 1$, the interstripe regions receive inputs from the interblob regions of $\mathrm{V} 1$, and the $\mathrm{CO}$ rich thick stripes receive inputs from layer $4 \mathrm{~B}$ of V1 (Livingstone and Hubel, 1984, 1987). Consistent with these inputs, the thin stripes tend to have a somewhat greater concentration of colorselective cells, the interstripes have a greater concentration of orientation-selective cells, and the thick stripes have a greater concentration of directionally selective cells (Livingstone and Hubel, 1984; DeYoe and Van Essen, 1985; Hubel and Livingstone, 1985, 1987; Shipp and Zeki, 1985).

Area V4, which receives inputs from both $\mathrm{CO}$-rich thin stripes and $\mathrm{CO}$-poor interstripe regions of $\mathrm{V} 2$, has both color-and formselective cells as well as many cells sensitive to both features (Desimone et al., 1985, 1992; DeYoe and Van Essen, 1985; Shipp and Zeki, 1985, 1989; Desimone and Schein, 1987; DeYoe et al., 1988; Zeki and Shipp, 1988, 1989; Schein and Desimone, 1990; DeYoe and Sisola, 1991; Van Essen et al., 1991). Although V4 also appears to have a modular organization (DeYoe et al., 1988; DeYoe and Sisola, 1991; Yoshioka et al., 1992), the geometry of the modules as well as their relation to color and form analysis remain unclear. The major outputs of V4 are to areas TEO and TE in the inferior temporal cortex (Desimone et al., 1980; Fenstemaker et al., 1984; Weller and Kaas, 1985, 1987; Ungerleider et al., 1986, DeYoe and Sisola, 1991; Distler et al., 1991, 1993; Weller and Steele, 1992), which contains neurons selective for many object features, such as color, shape, and texture (Desimone et al., 1984; Tanaka et al., 1991; Fujita et al., 1992).

Although neurons within the stations along the occipitotemporal pathway appear to play a significant role in the analysis of color and form information, it should be emphasized that this pathway is not equivalent to the "parvo" system. First, as statcd previously, the blobs in V1, which contribute to this pathway, receive magnocellular as well as parvocellular inputs (Lachica et al., 1992), and second, deactivation of magnocellular as well as parvocellular layers of the LGN affects the activity of V4 neurons (Ferrera et al., 1992).

In addition to the major anatomical routes into the temporal lobe, there are other, smaller, "side routes" or "bypasses" whose significance is as yet unclear. Two of the most intriguing ones are the direct projection from the foveal representation of V1 to area V4, bypassing V2 (Kuypers et al., 1965; Cragg and Ainsworth, 1969; Zeki, 1978a; Yukie and Iwai, 1985; Steele et al., 1991), and the direct projection from V2 to TEO, bypassing V4 (Morel and Bullier, 1990; Baizer et al., 1991; Distler et al., 1991, 1993; Weller and Steele, 1992). These bypass pathways may allow a certain amount of parallel processing across the areas of the occipitotemporal projection system. As a start in understanding the typcs of information that are conveyed along these pathways, we injected V4 and TEO with different retrograde tracers in the same animals, and we examined the distribution of V4- and TEO-projecting cells with respect to each other as well as to the CO-rich blobs of V1 and stripes of V2.

A preliminary report of this work has already appeared (Nakamura et al., 1991).

\section{Materials and Methods}

Four adult monkeys (Macaca mulatta) weighing 4.7-5.1 kg were used. In each monkey, we injected areas V4 and TEO with different retrograde tracers. In three monkeys (cases 1, 3, and 4), injections were placed in a single hemisphere, whereas in the fourth monkey (cases $2 \mathrm{~L}$ and $2 \mathrm{R}$ ) both hemispheres were injected. The tracers used (Sigma Chemical Company) were the fluorescent dyes fast blue (FB) and diamidino yellow (DY) as well as wheat germ agglutinin conjugated to horseradish peroxidase (WGA-HRP).

Injections of tracers into areas $V 4$ and TEO. Surgery was performed under aseptic conditions. Anesthesia was induced with ketamine hydrochloride $(10 \mathrm{mg} / \mathrm{kg}, \mathrm{i} . \mathrm{m}$.) and maintained with either sodium pentobarbital (i.v.) or a mixture of isoflurane gas (1-2\%) and oxygen to effect. Body temperature was maintained between $35^{\circ} \mathrm{C}$ and $37^{\circ} \mathrm{C}$ by heating pads (circulating warm water) surrounding the animal, and heart and respiratory rates were monitored throughout surgery. A midline incision of the skin and unilateral craniotomy were made in all animals, except in case 2 in which the skull was opened bilaterally and tracers were injected into both hemispheres. After the craniotomy, the dura was opened to expose the inferior occipital, lunate, posterior middle temporal, and superior temporal sulci.

In all cases, we attempted to inject the foveal representations of V4 and TEO as well as portions of either the upper or lower parafoveal visual field, or both. Injections into both areas were placed on the basis of the sulcal landmarks. Previous studies have shown that the lower field representation of V4 is on the prelunate gyrus and in the adjacent banks of the lunate and superior temporal sulci, and the upper field representation is in the inferior occipital sulcus, extending ventrally several millimeters onto the inferior occipital gyrus (Maguire and Baizer, 1984; Desimone and Ungerleider, 1986; Gattass et al., 1988). Just anterior to the upper field representation of V4 lies area TEO (Boussaoud et al., 1991). In TEO, the upper visual field is represented posteriorly while the lower field representation is located adjacent and anterior to it. Based on earlier mapping studies, we considered the V4/TEO border to be located just anterior to the inferior occipital sulcus and the TEO/ TE border to be located just anterior to the posterior middle temporal sulcus (Gattass et al., 1988; Distler ct al., 1991, 1993; Boussaoud ct al., 1991). We subsequently confirmed the visuotopic location of the injection sites based on the distribution of labeled cells in V2, although we recognize that this interpretation does not take into account the possibility of heterotopical connections.

Pressure injections were made using a $1 \mu \mathrm{l}$ Hamilton syringe with a beveled 27 gauge needle, which was guided into the appropriate site with the aid of an operating microscope. From three to eight injections of DY $(0.2 \mu \mathrm{l}$ each of $4 \%$ DY $)$ were placed into V4 in adjacent, closely spaced loci on the prelunate gyrus and in the anterior lip of the inferior occipital sulcus, and 3-12 injections of FB $(0.3 \mu \mathrm{l}$ each of $2 \% \mathrm{FB})$ were placed into TEO in closely spaced loci in and around the posterior middle temporal sulcus. In addition, in two cases, eight (case 1) or four (case 4$)$ injections of WGA-HRP $(0.2 \mu \mathrm{l}$ each of $5 \%$ WGA-HRP) were placed in a more anterior part of TEO in a sccond surgery performed $12 \mathrm{~d}$ after the first. We always injected the more sensitive retrograde tracer FB into TEO in order to maximize the chance of revealing weak V2-TEO projections.

Histological processing. Following a survival period of $14 \mathrm{~d}$ after DY and FB injections ( $2 \mathrm{~d}$ after WGA-HRP injections), the animals received a lethal dose of sodium pentobarbital and were perfused transcardially with cold $\left(4^{\circ} \mathrm{C}\right)$ saline, followed by 2 liters of $0.1 \mathrm{M}$ phosphate buffer (pH 7.4) with $5 \%$ glycerol at $4{ }^{\circ} \mathrm{C}$. The absence of fixative in the perfusion was necessary for the subsequent procedure of flattening the cortex. Following the perfusion, the brain was removed from the skull and photographed, and the cortex was flattened. Just prior to the flattening procedure, we injected the fluorescent dye dextran tetramethyl rhodamine (Molecular Probes) into the cortex along the lips of the sulci to mark them. To flatten the cortex, we first removed the arachnoid and vessels from its surface, physically opened the sulci, dissected away the white matter using cotton-tipped applicators, and then pressed the remaining gray matter between two glass plates (see Olavarria and Van Sluyters, 1985; Tootell and Silverman, 1985; Rosa et al., 1991). The flattened tissue was blocked and fixed in $3 \%$ paraformaldehyde in phosphate buffer between $15 \mathrm{~min}$ and $2 \mathrm{hr}$ (Rosa et al., 1991). The tissue was then washed with $5 \%$ glycerol in buffer, transferred into $10 \%$ glycerol in buffer (10-30 min), and then kept in $20 \%$ glycerol in buffer $(20 \mathrm{~min}$ to $12 \mathrm{hr}$ ) for cryoprotection. Finally, the tissue was embedded in a solution containing 3\% gelatin, 30\% albumin, and 3-4\% glutaraldehyde. 
After the albumin blocks had hardened, they were immersed into a $-70^{\circ} \mathrm{C} 2$-methyl butane $(95 \%)$ solution and maintained at this temperature until sectioned (Rosene et al., 1986).

Frozen sections, $50 \mu \mathrm{m}$ thick, were cut tangential to the cortical surface. Every third section was mounted on a gelatinized slide from $0.45 \%$ saline for fluorescent examination (and subsequent $\mathrm{CO}$ histochemistry; see below). An adjacent series of sections was mounted from $0.05 \mathrm{M}$ phosphate buffer for $\mathrm{CO}$ histochemistry. In cases 1 and 4 , the remaining sections were collected in a cold $\left(4^{\circ} \mathrm{C}\right)$ solution containing $600 \mathrm{ml}$ of glycerol, $600 \mathrm{ml}$ of ethylene glycol, and $1000 \mathrm{ml}$ of $0.05 \mathrm{M}$ phosphate buffer (pH 7.4) for subsequent HRP histochemistry. These HRP sections were kept in a freezer overnight at $-20^{\circ} \mathrm{C}$.

Sections for HRP histochemistry were processed according to the protocol of Gibson et al. (1984) modified from Mesulam (1978). After processing, the sections were mounted on gelatinized slides, dried, dehydrated, cleared, and coverslipped. $\mathrm{CO}$ histochemistry was performed according to a protocol (Rosa et al., 1991) modified from Silverman and Tootell (1987).

Data analysis. Each labeled neuron was charted using a computerized plotting system with position encoders attached to a microscope stage (Minnesota Datametrics). The section outlines, the locations of sulcal borders, and the locations of retrogradely labeled cells were entered into the computer, and enlarged sections $(10-12 \times)$ were plotted using a pen plotter. After the charting of labeled cells was complete, the same sections were further processed for $\mathrm{CO}$ histochemistry. Thus, there were two series of sections stained for $\mathrm{CO}$, one that was processed immediately after sectioning and another that was processed after examination of fluorescent label. Photographs of the CO-stained sections were overlaid with the computer plots to determine which CO structures contained the V4- and TEO-projecting cells. For ease of comparison, all figures were prepared so that the drawings of injection sites appear in the right hemisphere, although some of the experiments were done in the left. The lateral views of the hemispheres were drawn from photographs taken before the cortex was flattened.

\section{Results}

Wc present the distribution of V4- and TEO-projecting ncurons in V2 and the distribution of V4-projecting neurons in V1. Of the five hemispheres injected, four had overlapping distributions of V4- and TEO-projecting neurons (cases 1, 2L, 2R, and 3 ). Of these four, we were able to determine with confidence the CO stripe pattern in V2 in three (cases 1, 2R, and 3), and these cases will be described in detail.

\section{Distribution of labeled cells in V2}

Case 1 . In this case, 7 injections of DY were placed in V4 along the prelunate gyrus, 11 injections of $\mathrm{FB}$ were placed in TEO just caudal to the posterior middle temporal sulcus, and 8 injections of WGA-HRP were placed farther anteriorly in TEO, just rostral to the posterior middle temporal sulcus (Figs. $1 A, B$, 2A,B).

Figure 1 shows the resulting distribution of labeled cells in the dorsal part of V2. The figure illustrates the labeling from only the DY and WGA-HRP injections, as only DY and WGAHRP labeled cells were found in overlapping regions of this part of V2. The location of DY-labeled cells in V2 indicated that the V4 injections involved much of this area's lower visual field representation, from the fovea to the mid-periphery (Gattass et al., 1981). The location of WGA-HRP labeled cells indicated that the rostrally placed TEO injections were located mainly in the region representing the foveal and parafoveal lower visual field (Gattass et al., 1981). (There was, in addition, a small, separate WGA-HRP injection site in TEO in the region representing the upper peripheral visual field; this injection site resulted in a small cluster of labeled cells in ventral V2.)

As shown in Figure $1 C$ (middle), V4-projecting neurons in $\mathrm{V} 2$ were located in heavily labeled bands of $2-4 \mathrm{~mm}$ in width, oriented orthogonal to the V1/V2 border. The bands were sep- arated by gaps of 1-2 $\mathrm{mm}$. The labeled bands nearly filled the CO-rich thin stripe and CO-poor interstripe regions, but largely avoided the thick stripes. Occasionally, dense accumulations of labeled cells were located just inside the boundaries of the thick stripes, with some labeled cells extending into the interior.

As shown in Figure $1 C$ (top), TEO-projecting neurons in V2 were intermingled with the V4-projecting ones but were far sparser. Like the cells projecting to V4, those projecting to TEO formed several bands of about $3 \mathrm{~mm}$ in width, separated by $1-$ $2 \mathrm{~mm}$ gaps, oriented orthogonal to the V1/V2 border. TEOprojecting cells were largely confined to the thin stripes and interstripe regions, with only a few cells located in the thick stripes. Seventeen percent (37 of 218) of the TEO-projecting cells were double labeled (stars in Fig. $1 C$, top), that is, also projected to V4. Most of the double-labeled neurons were distributed in thin stripes and interstripe regions, but three of them were situated at the border of a CO-rich thick stripe.

In addition to the bands of labeled cells running orthogonal to the V1/V2 border, V4-projecting cells were also found in a strip running parallel to the V2/V3 border and intersecting the orthogonal bands (Fig. $1 C$, middle). These cells were located about $8 \mathrm{~mm}$ from the V1/V2 border, and, therefore, in the absence of any additional criteria, could not be assigned to either V2 or V3. Intermingled with V4-projecting cells, a small number of TEO-projecting neurons were also distributed within this region, in a wide strip spanning two CO-rich thick/thin cycles at the presumed V2/V 3 border (Fig. $1 C$, top).

Figure 2 shows the resulting distribution of labeled cells in the ventral part of $\mathrm{V} 2$ in the same case. In this part of $\mathrm{V} 2$, almost no DY-labeled cells resulting from the V4 injections were obscrved, but the FB labcling from the posteriorly placed TEO injections was moderately heavy. The location of the FB-labeled cells indicated that these posteriorly placed TEO injections were located in the region representing the foveal and parafoveal upper visual field (Gattass et al., 1981). As shown in Figure $2 C$, TEO-projecting neurons in ventral V2 were located in heavily labeled bands of $1.5-4 \mathrm{~mm}$ in width, oriented orthogonal to the $\mathrm{V} 1 / \mathrm{V} 2$ border. The bands were separated by gaps of 2-3 $\mathrm{mm}$. Labeled neurons were mainly distributed in $\mathrm{CO}$-poor interstripe regions, but considerable numbers were in CO-rich thin stripes as well. Occasionally, labeled cells were also found just inside the boundaries of the CO-rich thick stripes, with a few TEOprojecting cells extending into the interior. Because of the lack of overlap between the distributions of DY- and FB-labeled cells, no cell was double labeled with these two tracers.

Case $2 R$. In this case, 8 injections of DY were placed in V4, and 11 injections of FB were placed in TEO (Fig. $3 A, B$ ). Three of the V4 injections were located in the lower part of the prelunate gyrus, and five were placed along the anterior lip of the inferior occipital sulcus. According to the distribution of labeled cells in V2, these V4 injections fell largely in the area's upper visual field representation, but also in some of the representation of the parafoveal lower visual field (Gattass et al., 1981). The TEO injections were placed in the region surrounding the posterior middle temporal sulcus; the location of labeled cells in $\mathrm{V} 2$ indicated that the region injected included the foveal and parafoveal representations, in both the upper and lower visual field. Both the V4 and TEO injection sites apparently spared the representation of the vertical meridian in the upper and lower visual fields, as labeled DY and FB cells were concentrated in the more anterior parts of $\mathrm{V} 2$, away from $\mathrm{V} 1 / \mathrm{V} 2$ border dorsally as well as ventrally. Because V2 does not project con- 


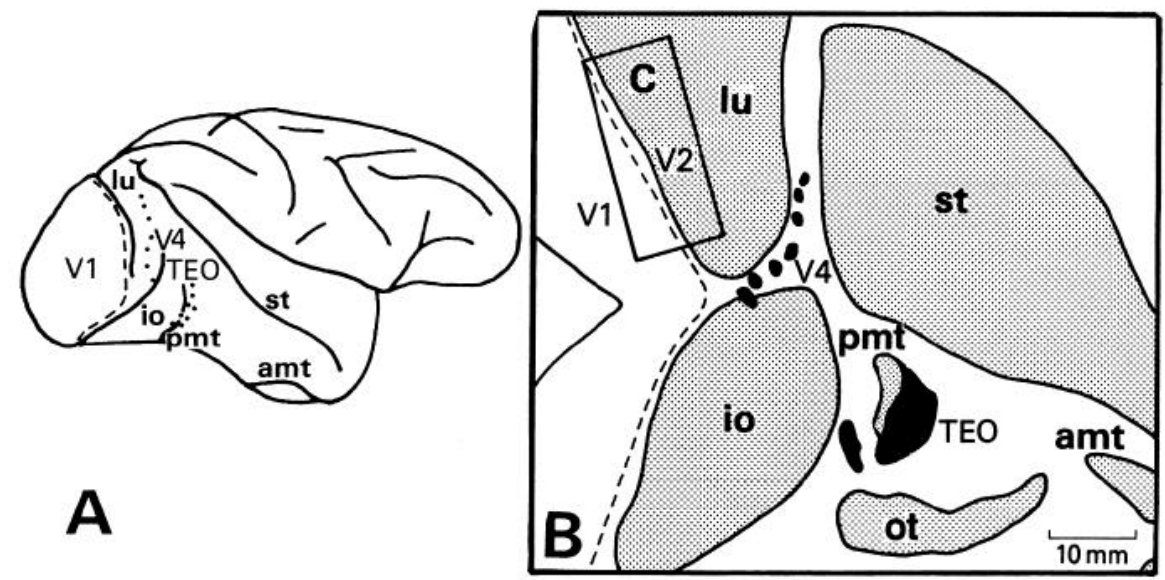

Figure 1. Distribution of TEO- and V4-projecting neurons in a flattened preparation of a dorsal part of $\mathrm{V} 2$ in case 1. Injection sites of DY in V4 and WGA-HRP in TEO are shown on the lateral view of the brain (dots in $A$ ) and on the flattened cortex (black dots and solid black regions in $B$ ). The extent of the individual DY injection sites, which included all cortical layers, ranged from 1.2 to $2.8 \mathrm{~mm}$ in diameter. The WGAHRP injections also included all cortical layers; the posterior injection site was about $6.0 \times 2.5 \mathrm{~mm}$ and the anterior one was about $11.0 \times 5.0 \mathrm{~mm}$. In $A-C$, the $\mathrm{V} 1 / \mathrm{V} 2$ border is indicated with a dashed line. In $B$, the lips of the sulci are drawn with solid lines, and the cortex within the sulci is shaded gray. Data within the box outlined in $B$ is shown enlarged in $C$. In $C$ (top), TEOprojecting neurons are indicated with triangles, and neurons projecting to both TEO and V4 are indicated with stars. Each triangle and star indicates a single-labeled cell. In $C$ (middle), V4-projecting neurons are indicated with open circles. A small circle indicates a single cell; a medium-sized circle, five cells; and a large circle, 25 cells. In $C$ (top and middle), labeled cells are from two sections overlaid and aligned using sulcal borders and blood vessels and are plotted in relationship to the $\mathrm{CO}$ stripes of V2. CO-rich thin stripes are indicated with broken lines, and $\mathrm{CO}$-rich thick stripes with solid lines. These stripes were drawn from the photograph of the section shown in $C$ (bottom). For ease of comparison, the injection sites are illustrated here in a right hemisphere, although the experiment was done in the left. Sulcal abbreviations in this and subsequent figures: amt, anterior middle temporal sulcus; $i o$, inferior occipital sulcus; $l u$, lunate sulcus; $o t$, occipitotemporal sulcus; pmt, posterior middle temporal sulcus; st, superior temporal sulcus.
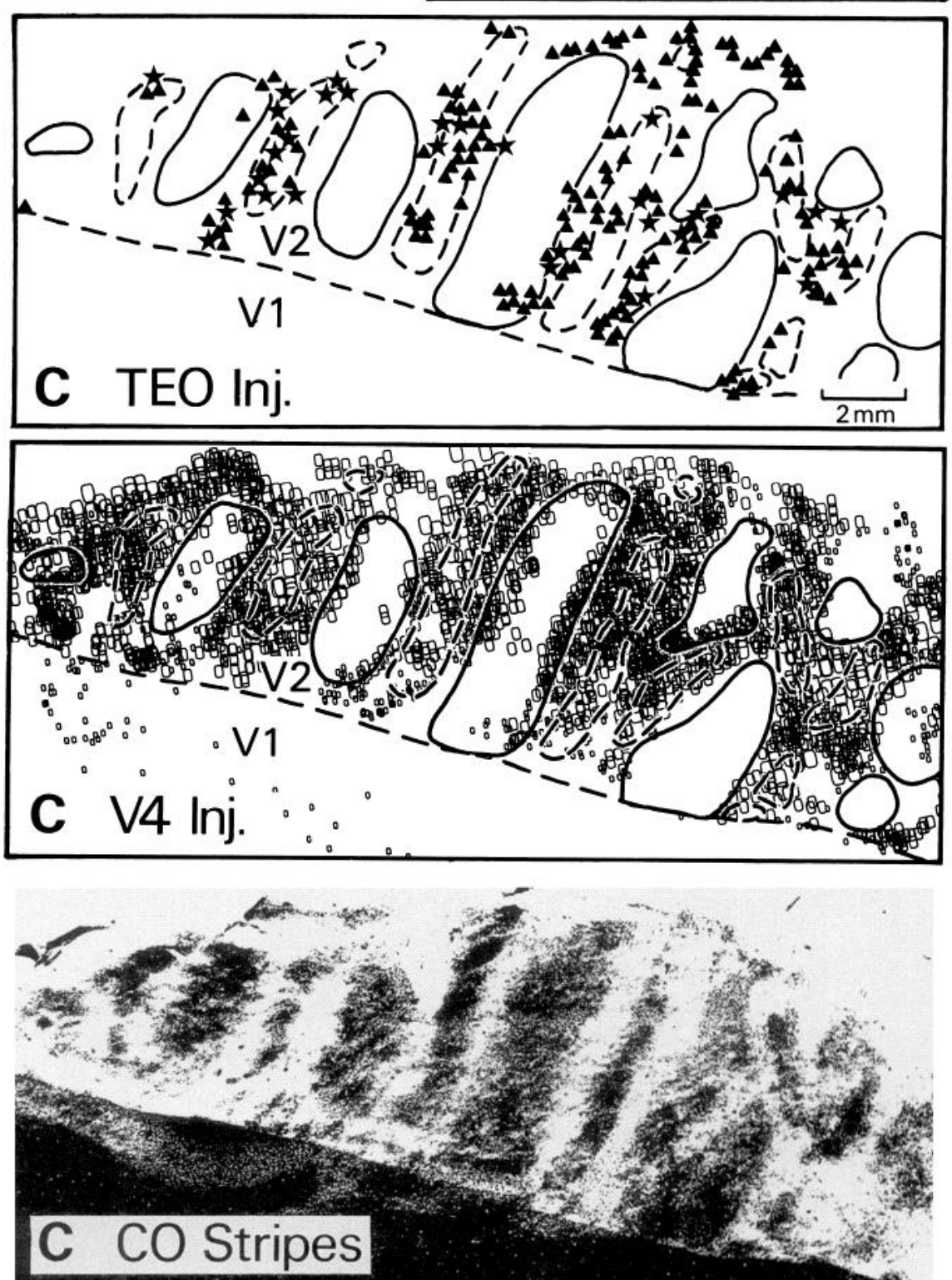

tralaterally to either V4 or TEO, except at the representation of the vertical meridian (Ungerleider et al., 1983; Tanaka et al., 1990), we are confident that the injections placed in the other hemisphere did not contribute significantly to either the DY or FB labeling in this case.
Figure 3 illustrates the resulting distribution of labeled cells within dorsal and ventral V2. V4-projecting neurons were found in both the lower field representation of V2, within the lunate sulcus, and in the upper field representation located in the inferior occipital sulcus (Fig. $3 C, D$, bottom). As in the previous 


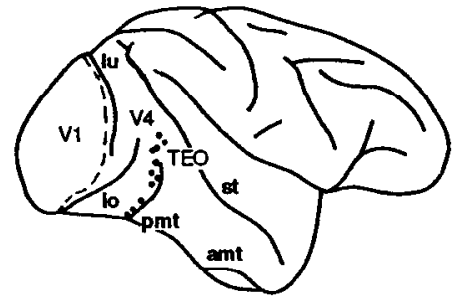

A

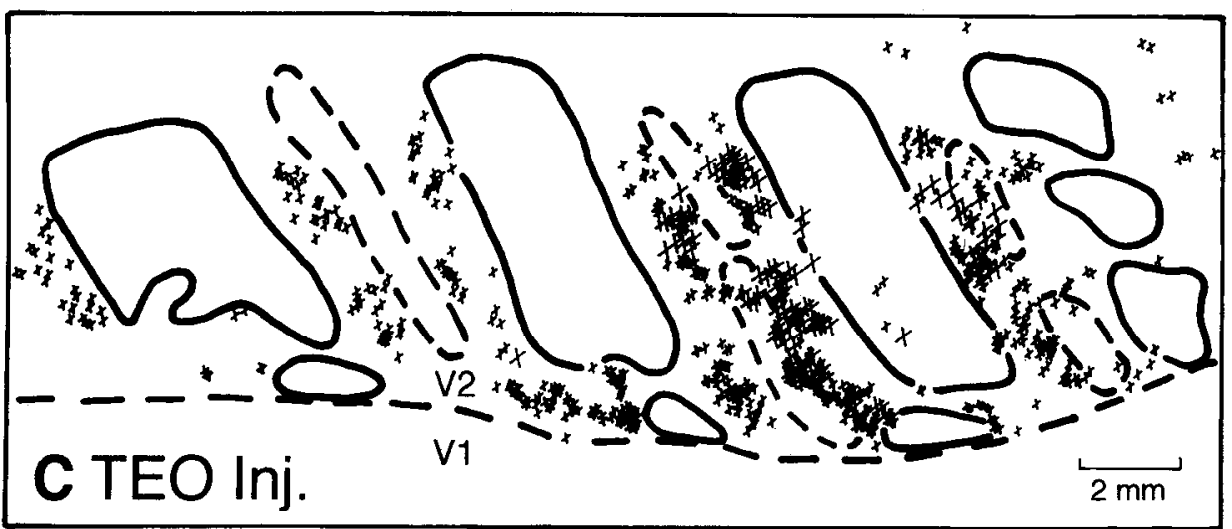

Figure 2. Distribution of TEO-projecting neurons in a flattened preparation of a ventral part of $\mathrm{V} 2$ in case 1. Injection sites of FB in TEO are shown on the lateral view of the brain (dots in $A$ ) and on the flattened cortex (dots in $B$ ). The extent of the individual FB injection sites, which included all cortical layers, ranged from 0.5 to $1.8 \mathrm{~mm}$ in diameter. Area in the box outlined in $B$ is shown enlarged in $C$. In $C$, TEOprojecting cells are indicated with crosses; a small cross indicates one TEOprojecting cell, and a large cross, five TEO-projecting cells. Labeled cells are from three sections overlaid and aligned using sulcal borders and blood vessels and are plotted in relationship to the $\mathrm{CO}$ stripes of V2. Although the experiment was done in the left hemisphere, the injection sites are illustrated here in the right. All abbreviations and other conventions are as in Figure 1. case, neurons projecting to V4 in this case were distributed in bands oriented orthogonal to the $\mathrm{V} 1 / \mathrm{V} 2$ border; these bands were $2-3 \mathrm{~mm}$ in width separated by $1-2 \mathrm{~mm}$ gaps. The bands were largely confined to the thin stripe and interstripe regions, but a few cells were also located within the thick stripes. Neurons projecting to TEO were again intermingled with those projecting to $\mathrm{V} 4$, but in this case there were far fewer TEO-projecting neurons. Consequently, the labeled region appeared as clusters of cells rather than as bands. However, the cells were nearly all confined to the CO-rich thin stripes and CO-poor interstripe regions (Fig. $3 C, D$, top), consistent with the previous case. Double-labeled cells (stars in Fig. $3 C, D$, top; arrows in Fig. 4) constituted 19\% (42 of 225) of the TEO-projecting cells, and were found mainly in the foveal representation of V2 (Fig. 4), where the structure of the $\mathrm{CO}$ staining pattern was less clear. In the regions where CO-rich stripes were apparent, double-labeled cells were confined to the thin stripes and interstripe regions.

Case 3. Three injections of DY were placed into the foveal representation of V4, just anterior to the tip of the lunate sulcus, and three of FB were placed into the foveal representation of TEO, above the posterior middle temporal sulcus (Fig. $5 A, B$ ). DY - and FB-labeled cells were located in overlapping regions on the posterior bank of the lunate sulcus, corresponding to the foveal representation in the lower visual field.

As in the previous cases, cells projecting to V4 (DY labeled) were concentrated in bands of about $2-3 \mathrm{~mm}$ in width, with $1-$ $2 \mathrm{~mm}$ gaps, oriented orthogonal to the V1/V2 border (Fig. $5 C$, bottom). The bands were located largely within the thin stripe and interstripe regions, with some extension into the thick stripes, particularly around their borders. Unlike the finding in the previous two cases, the labeled bands merged in V2 at the V1/V2 border, forming a continuously labeled zone at the border. Also, unlike the other cases, the $\mathrm{CO}$-rich stripes appeared to fade away before reaching the $\mathrm{V} 1 / \mathrm{V} 2$ border. Thus, this continuously labeled zone seemed to occupy a CO-poor region.

The TEO-projecting neurons were sparser than in either of the two previous cases, probably because there were fewer injection sites. However, nearly all of the cells were located in the thin stripes and interstripes (Fig. $5 C$, top), consistent with the other cases. Two double-labeled neurons were found (stars in Fig. $5 C$, top), constituting about $6 \%$ ( 2 of 33 ) of the total population of TEO-projecting cells. One of them was in a CO-rich thick stripe, at the border with a $\mathrm{CO}$-poor interstripe region, and the other was in an interstripe region.

Cases $2 L$ and 4 (not illustrated). In case $2 \mathrm{~L}$, we placed $8 \mathrm{DY}$ injections into the lower portion of the prelunate gyrus and along the anterior lip of the inferior occipital sulcus, regions in V4 representing foveal and parafoveal vision in the lower and upper visual fields, respectively, and 12 FB injections surrounding the posterior middle temporal sulcus, a region in TEO representing the same portions of the visual field. Both V4- and TEO-projecting cells were found dorsally and ventrally in V2, and, as in the previously described cases, the two classes of cells were intermingled. However, $\mathrm{CO}$ staining in this case was not satisfactory, precluding the study of the relation between the sites of labeled cells and the pattern of $\mathrm{CO}$ staining. Double-labeled neurons were about $13 \%$ (12 of 89 ) of the total population of TEO-projecting neurons.

In case 4, we placed four injections of DY into V4, six of FB into TEO, and four of WGA-HRP into a somewhat more antcrior location of TEO. The distribution of labeling in V2 indicated that the DY injection sites included the region of V4 


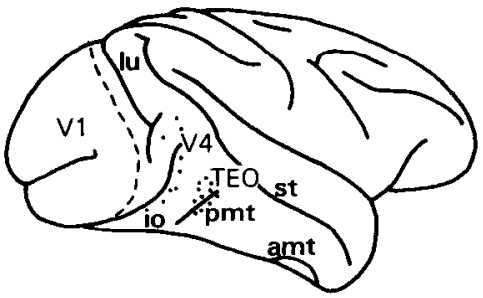

A
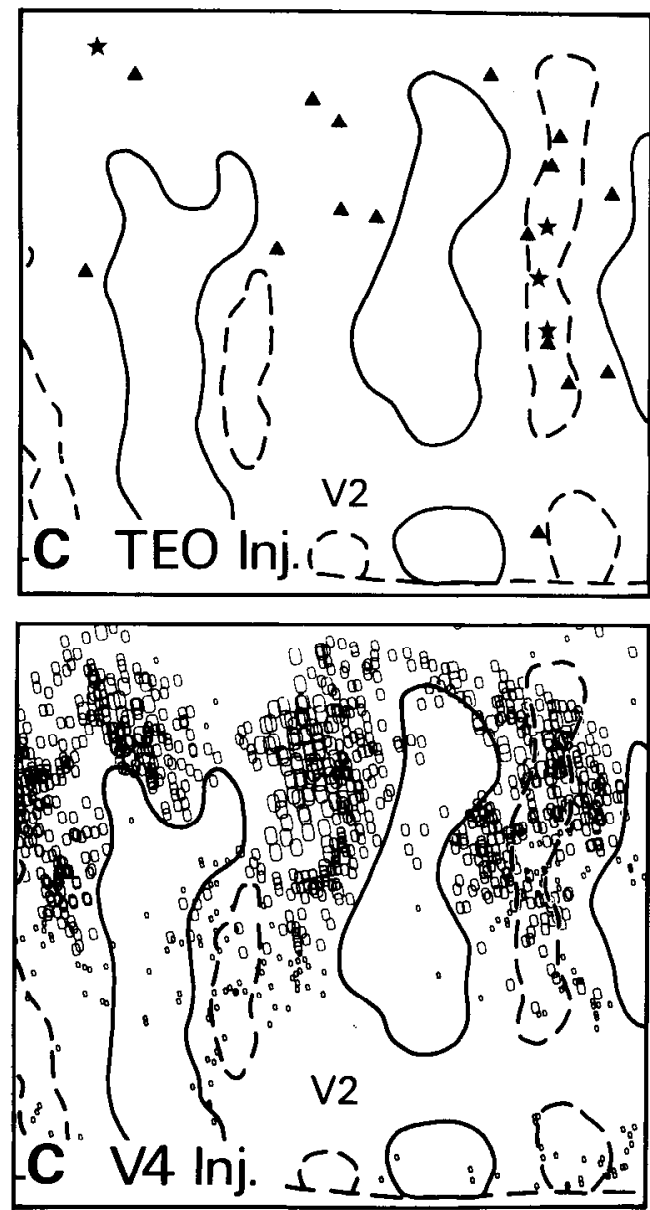
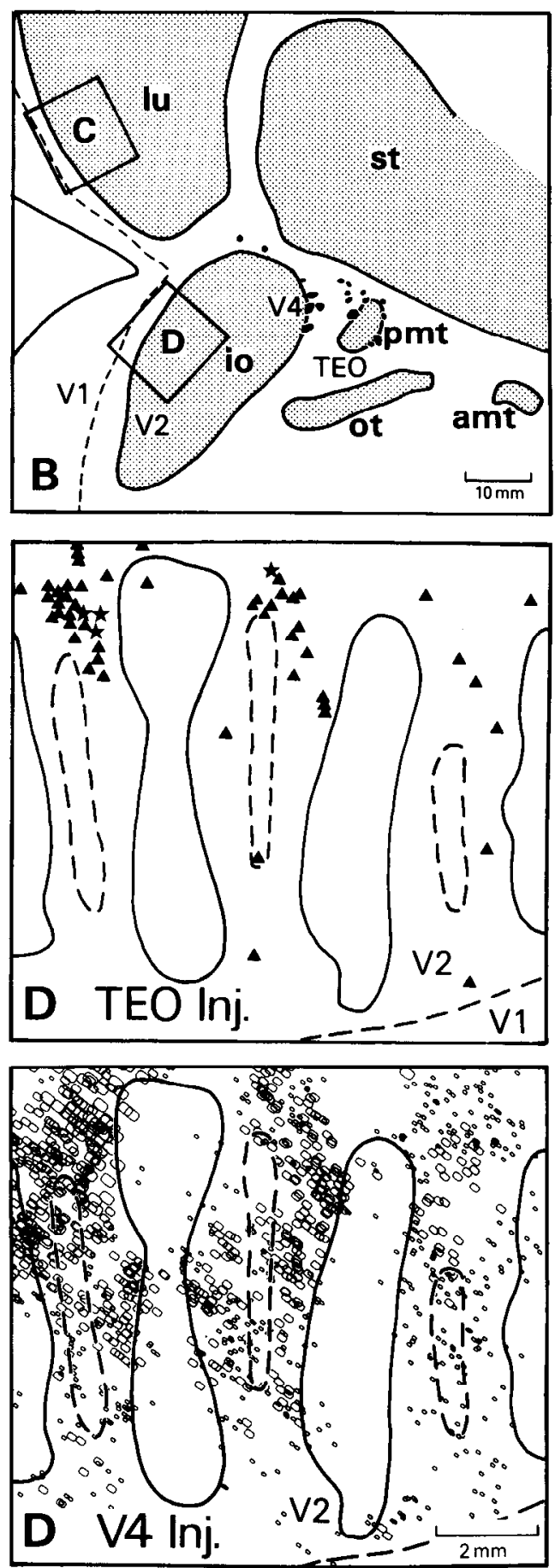

Figure 3. Distribution of TEO- and V4-projecting neurons in a flattened preparation of dorsal and ventral parts of $V 2$ in case $2 R$. The extent of the individual injection sites, which included all cortical layers, ranged from 0.5 to $2.0 \mathrm{~mm}$ in diameter for the DY sites and from 0.6 to $1.5 \mathrm{~mm}$ in diameter for the FB sites. For abbreviations and all conventions, see Figure 1. representing the foveal lower visual field, the FB injection sites included the region of TEO representing the foveal upper visual field, and the WGA-HRP injection sites included the region of TEO representing the center of gaze. Thus, V4- and TEO-projecting neurons were mostly segregated in different parts of V2, with very little overlap of the two cell populations. Since the region in V2 containing TEO-projecting neurons that were labeled with WGA-HRP was so restricted, only the distribution of TEO-projecting neurons that were labeled with FB will be described. These neurons formed bands of $1.0-1.5 \mathrm{~mm}$ in width, separated by $3-4 \mathrm{~mm}$ gaps, oriented orthogonal to the V1/V2 border, similar to the other cases. Although the CO staining was less satisfactory in this case than in cases $1,2 \mathrm{R}$, and 3 , it appeared that the TEO-projecting neurons were distributed mainly in CO-poor interstripe regions. Interestingly, V4-projecting cells were located at V2's vertical meridian representation, and, as in case 3, formed a continuously labeled zone in V2 along the V1/V2 border. This zone appeared to span all stripe and interstripe regions.

\section{Distribution of labeled cells in V1}

In cases $1,2 \mathrm{~L}, 3$, and 4, V4-projecting neurons were found in $\mathrm{V} 1$. In all four cases, most of the labeled cells were in the foveal representation of $\mathrm{V} 1$, with scattered cells in the parafoveal rep- 
resentation. All but a few cells were located in the supragranular layers, presumably layers 2 and 3 .

In all four cases with V4-projecting cells in V1, we were able to determine the relation between the location of the labeled cells and the pattern of $\mathrm{CO}$ staining. The data from case 3 have been selected to illustrate this relationship. In this case, the labeled cells were located near the V1/V2 border in the foveal representation. As shown in Figure $5 D$ (top), the labeled cells appeared to be evenly distributed across CO-rich blob and COpoor interblob regions. This was a consistent finding in the four cases. To test quantitatively whether the distribution of labeled cells was indeed random with respect to the CO blobs, we computed the density of labeled cells (cells $/ \mathrm{mm}^{2}$ ) separately for blob and interblob regions. The computation was performed on a heavily labeled region of about $7 \mathrm{~mm}^{2}$ in the foveal representation of $\mathrm{V} 1$, which is shown in the upper left part of Figure $5 D$ (top). The density was 71 cells $/ \mathrm{mm}^{2}$ in the blobs and 65 cells/ $\mathrm{mm}^{2}$ in the interblob regions, which was not a significant difference $\left(\chi^{2}=0.387 ; p>0.5\right)$. It should be noted that in all cases the density of labeled cells in both the blob and interblob regions of V1 was far less than the density of labeled cells in the thin stripe and interstripe regions of $\mathrm{V} 2$ (see Figs. $1 C$, middle; $5 C$, bottom).

\section{Discussion}

The present findings confirm earlier reports of direct projections from foveal V1 to V4 (Kuypers et al., 1965; Cragg and Ainsworth, 1969; Zeki, 1978a; Yukie and Iwai, 1985; Steele et al., 1991 ) and from V2 to TEO (Morel and Bullier, 1990; Baizer et al., 1991; Distler et al., 1991, 1993; Weller and Steele, 1992). They also localize the source of the projections within the structural modules of V1 and V2. By placing injections of different tracers in topographically corresponding portions of V4 and TEO, we found that the projections from V2 to both V4 and TEO originate in the CO-rich thin stripes and CO-poor interstripe regions, although the projections to TEO are much sparser than those to V4. Moreover, we found that the projection from foveal V1 to V4 originates in both the CO-rich blobs and COpoor interblob regions.

The information conveyed along the occipitotemporal pathway. The intermingling of V2 cells projecting to areas V4 and TEO suggests that similar information is relayed to both areas. This conclusion is supported by the large proportion of doublelabeled cells projecting to these areas, 6-19\% of the TEO-projecting cells having been double labeled in the cases with significant overlap of V4- and TEO-projecting cells. Although there is still some question about the relative proportions of colorand orientation-selective cells in the CO-rich thin stripe and $\mathrm{CO}$-poor interstripe regions of $\mathrm{V} 2$, it is commonly accepted that these two stripe systems, taken together, contain many colorand form-selective cells, as well as some cells selective for both (Livingstone and Hubel, 1984; DeYoe and Van Essen, 1985; Hubel and Livingstone, 1985, 1987). The form-selective cells include both orientation-selective cells, end-stopped cells, and "special complex" cells that respond best to a small stimulus within a large receptive field (Hubel and Livingstone, 1985, 1987). What the thin stripe and interstripe regions lack are large numbers of directionally selective cells, which are mainly located instead in the CO-rich thick stripes that project to area MT (DeYoe and Van Essen, 1985; Shipp and Zeki, 1985; Hubel and Livingstone, 1987). We found only a few labeled cells in

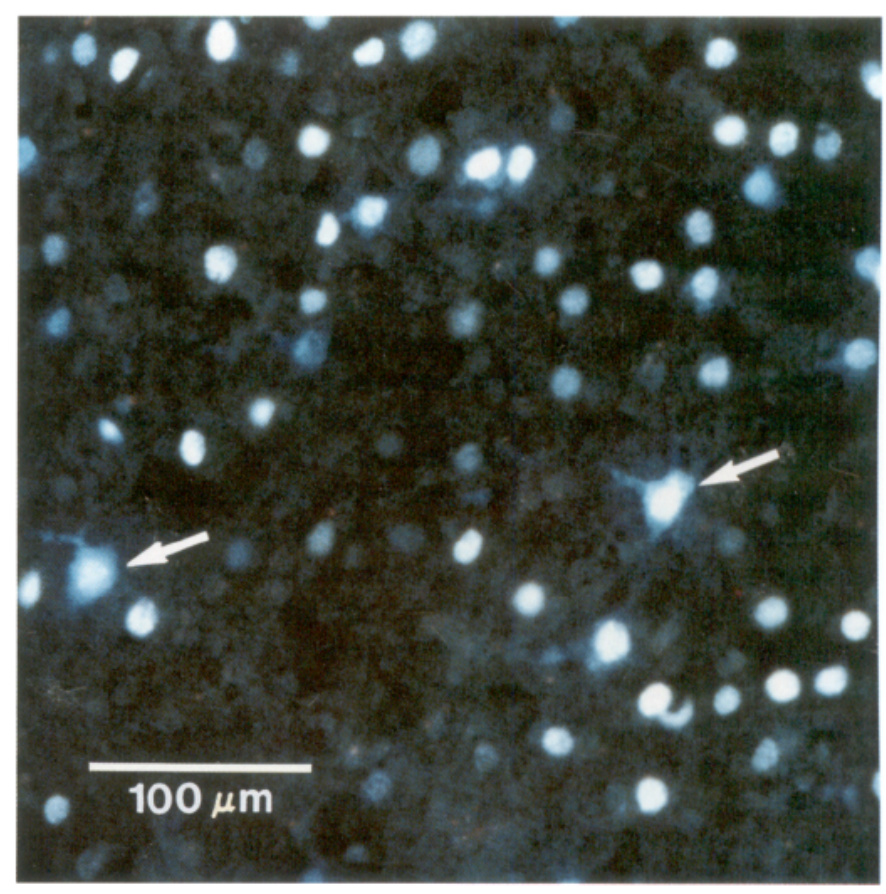

Figure 4. Photomicrograph indicating the presence of several doublelabeled cells (see arrows) in the foveal representation of $\mathrm{V} 2$ after injections of DY in V4 and FB in TEO in case $2 \mathrm{R}$.

the thick stripes projecting to either V4 or TEO, but it is not known if these were directionally selective.

Area V4 continues the analysis of color and form information relayed from V2, with cells sensitive to color, orientation, size, and shape (Zeki, 1973, 1978b,c, 1983a,b; Desimone and Schein, 1987; Schein and Desimone, 1990). Many cells in V4 have receptive fields with large suppressive surrounds that are also color and form selective, such that they respond best to stimuli that differ from their background in color or form (Desimone et al., 1985, 1992; Desimone and Schein, 1987; Schein and Desimone, 1990). Less is known about cells in TEO, but Tanaka et al. (1991) have recently reported that some TEO cells are selective for complex shapes as well as color.

In addition to the "bypass" route from the thin stripe and interstripe regions of $\mathrm{V} 2$ to area TEO, we also found a "bypass" projection from the blob and interblob regions of foveal $\mathrm{V} 1$ to area V4. Just as the projection from V2 to TEO involves far fewer cells than the projection from V2 to V4, so too does the projection from $\mathrm{V} 1$ to $\mathrm{V} 4$ involve far fewer cells than the projection from $\mathrm{V} 1$ to $\mathrm{V} 2$. As with the thin stripe and interstripe regions of $\mathrm{V} 2$, the relative contribution of the blob and interblob regions to color and form is still somewhat unsettled, but together they carry both types of information (Livingstone and Hubel, 1984; Tootell et al., 1988a,c; Lennie et al., 1990).

The significance of bypass projections. Given the disparity between the large numbers of cells projecting within the mainstream routes along the occipitotemporal pathway (i.e., from $\mathrm{V} 1$ via areas V2 and V4 into area TEO) and the small numbers projecting along the bypass routes (i.e., foveal V1 to V4 and V2 to TEO), how significant can the bypass routes be for visual processing? One possibility is that they provide a means for coarse-grained information to arrive rapidly in the temporal lobe. This advance information about the current stimulus might aid in constructing the initial representation of its overall 


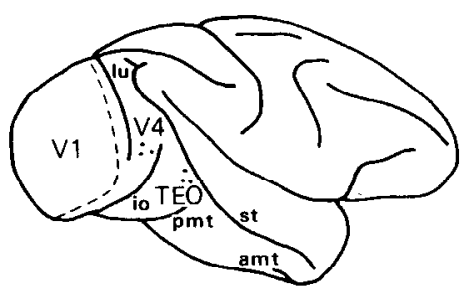

A

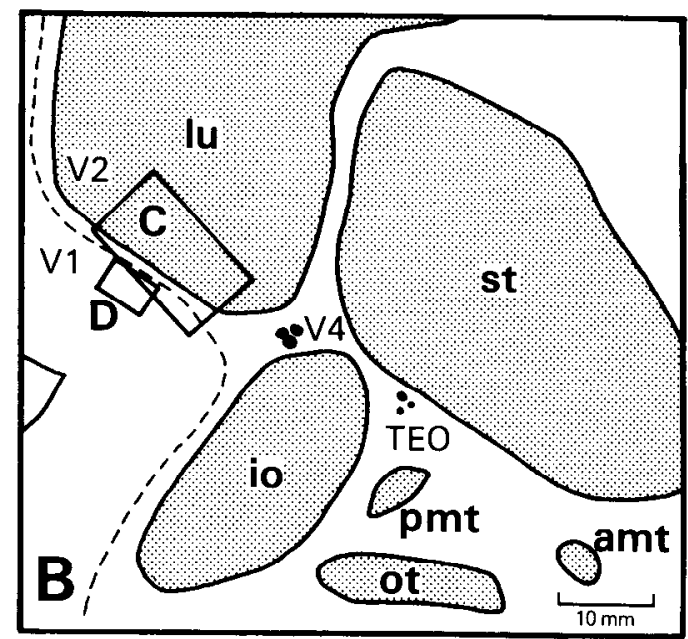

Figure 5. Distribution of TEO- and V4-projecting neurons in a dorsal part of V2, and V4-projecting neurons in an adjacent portion of $\mathrm{V} 1$ in a flattened preparation of the cortex in case 3 . The extent of the individual injection sites, which included all cortical layers, ranged from 1.3 to $1.8 \mathrm{~mm}$ in diameter for the DY sites and from 0.8 to $1.5 \mathrm{~mm}$ in diameter for the FB sites. $A-C$, All abbreviations and conventions are as in Figure 1. D, Location of V4-projecting neurons in relationship to the $\mathrm{CO}$-rich blobs and $\mathrm{CO}$-poor interblob regions of V1. Each small circle indicates one V4projecting neuron. The CO-rich blobs are indicated by heavy solid lines. Labeled cells are plotted from the same section that was stained for $\mathrm{CO}$; a photomicrograph of this stained section is shown at the bottom.
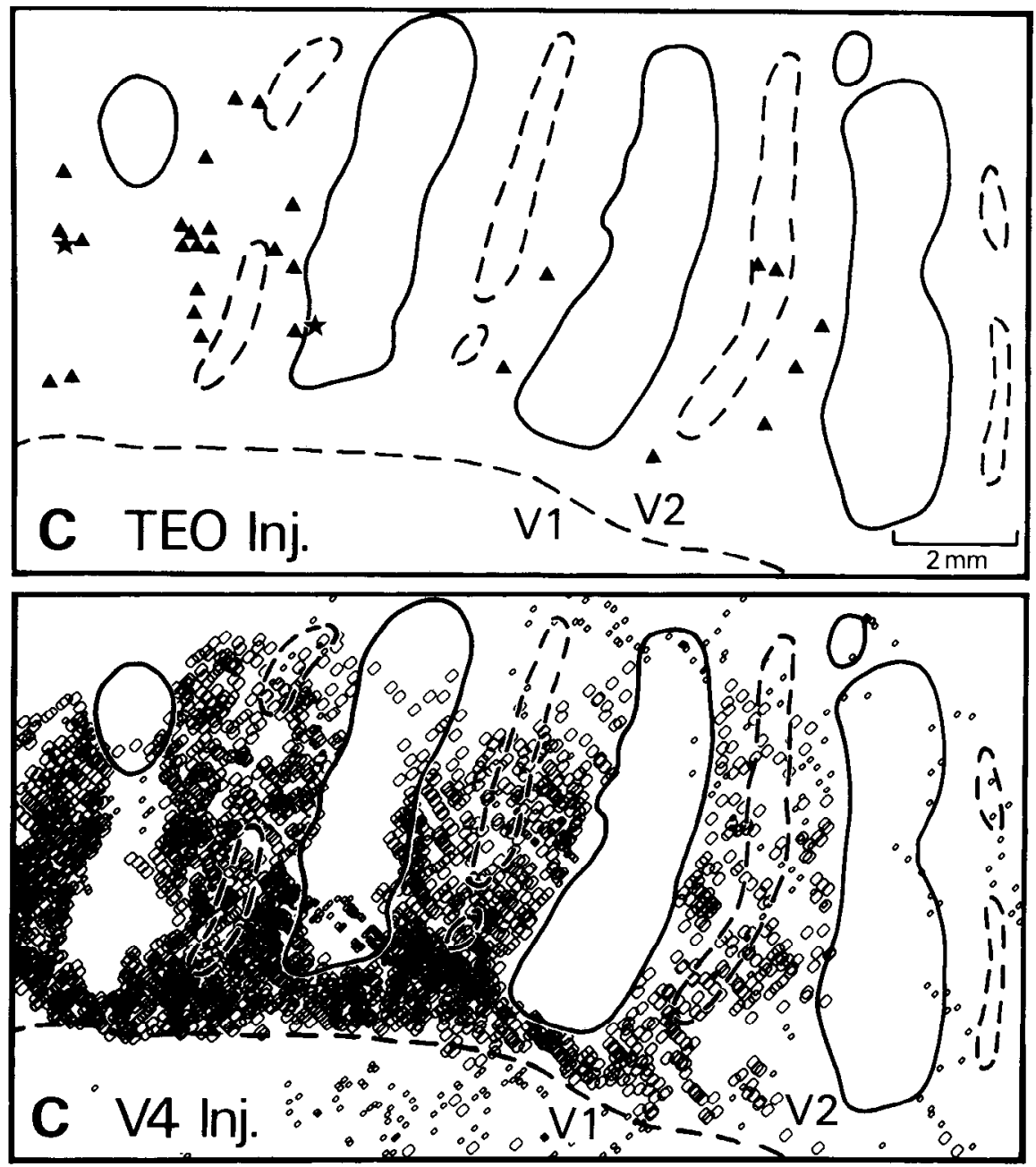

(low-pass) shape and color within area TE, with the fine-grained information arriving later to fill in the important details. Recent recordings in the most anterior portion of area TE have shown minimum response latencies to be less than $80 \mathrm{msec}$ (Miller et al., 1993), which does not allow much time for processing along the route.

In addition to their role in normal visual processing, bypass projections may also play an important role in sparing of function following brain damage. Lesions of V4 cause impairments in both color and form vision, but the impairments arc smaller than one would expect if the lesion had disconnected VI from area TE (Heywood and Cowey, 1987; Desimone et al., 1990; Schiller and Lee, 1991; Walsh et al., 1992a,b; see especially Wild et al., 1985; Heywood et al., 1992). We have recorded from cells in area TE following lesions of V4 and have in fact found robust, stimulus-selective responses (Desimone et al., 1990), indicating that visual information can indeed reach TE bypassing V4. The bypass projection from V2 directly to TEO 

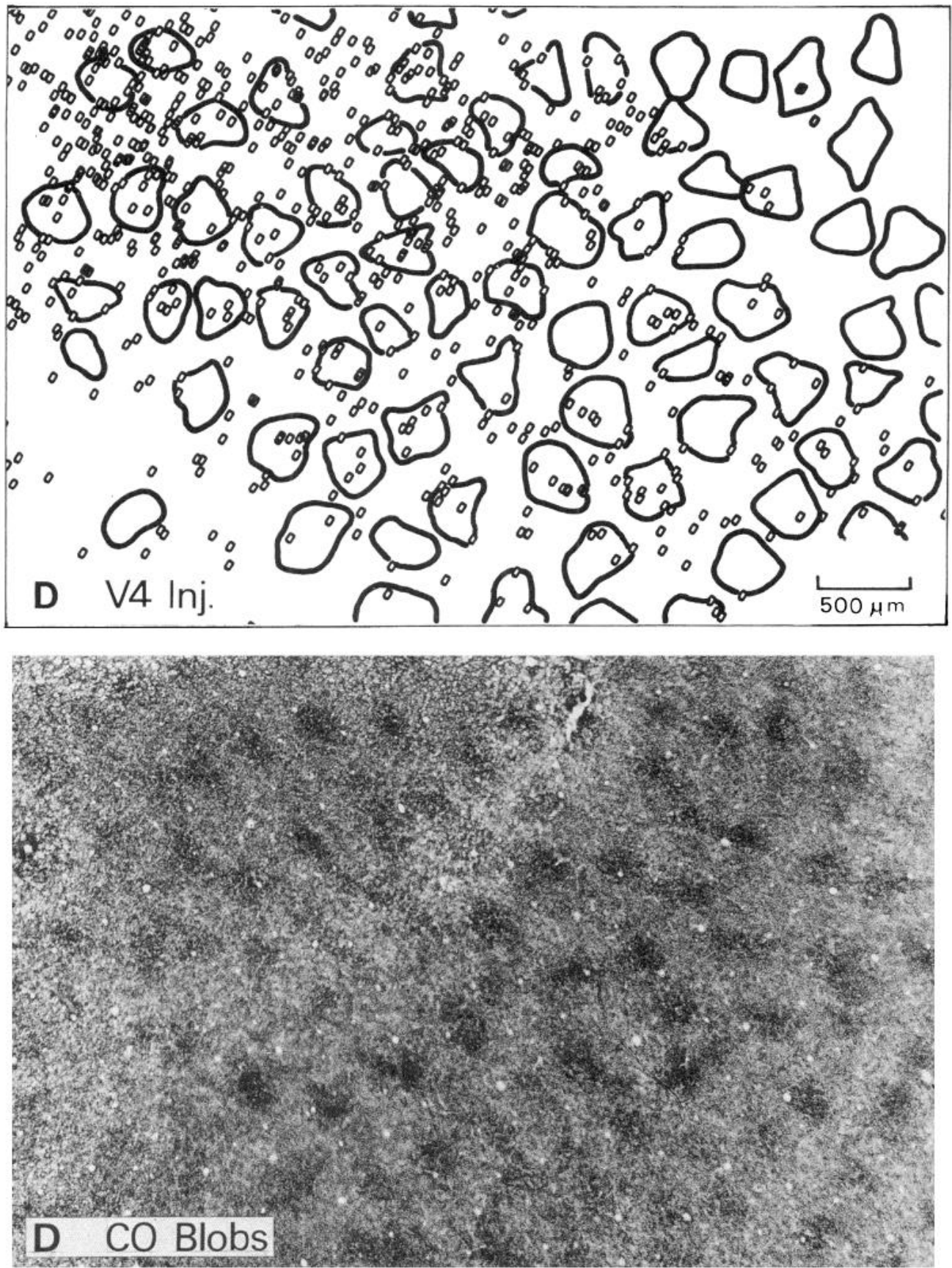

Figure 5. Continued.

might thus explain both the partial sparing of color and form vision and the visual activation of TE neurons after V4 lesions. Given the bypass route from the foveal representation of $\mathrm{V} 1$ directly to V4, the same partial sparing would be predicted after V2 lesions affecting the foveal visual field.

\section{References}

Allman J, Zucker S (1990) Cytochrome oxidase and functional coding in primate striate cortex: a hypothesis. Cold Spring Harbor Symp Quant Biol 55:979-982.

Baizer JS, Ungerleider LG, Desimone R (1991) Organization of visual inputs to the inferior temporal and posterior parietal cortex in macaques. J Neurosci 11:168-190.

Blasdel GG, Lund JS (1983) Termination of afferent axons in macaque striate cortex. J Neurosci 3:1389-1413.
Blasdel GG, Lund JS, Fitzpatrick D (1985) Intrinsic connections of macaque striate cortex: axonal projections of cells outside lamina $4 \mathrm{C}$. J Neurosci 5:3350-3369.

Boussaoud D, Desimone R, Ungerleider LG (1991) Visual topography of area TEO in the macaque. J Comp Neurol 306:554-575.

Carroll EW, Wong-Riley MTT (1984) Quantitative light and electron microscopic analysis of cytochrome oxidase-rich zones in the striate cortex of the squirrel monkey. J Comp Neurol 222:1-17.

Condo GJ, Casagrande VA (1990) Organization of cytochrome oxidase staining in the visual cortex of nocturnal primates (Galago crassicaudatus and Galago senegalensis). I. Adult patterns. J Comp Neurol 293:632-645.

Cragg BG, Ainsworth A (1969) The topography of the afferent projections in the circumstriate visual cortex of the monkey studied by the Nauta method. Vision Res 9:733-747.

Cusick CG, Kaas JH (1988) Cortical connections of area 18 and dorsolateral visual cortex in squirrel monkeys. Vis Neurosci 1:211-237. 
Desimone R, Schein SJ (1987) Visual properties of neurons in area V4 of the macaque: sensitivity to stimulus form. J Neurol $57: 835-$ 868.

Desimone R, Ungerleider LG (1986) Multiple visual areas in the caudal superior temporal sulcus of the macaque. J Comp Neurol 248: 164-189.

Desimone R, Ungerleider LG (1989) Neural mechanisms of visual processing in monkeys. In: Handbook of neuropsychology, Vol 2 (Boller F, Grafman J, eds), pp 267-299. Amsterdam: Elsevier.

Desimone R, Fleming J, Gross CG (1980) Prestriate afferents to inferior temporal cortex: an HRP study. Brain Res 184:41-55.

Desimone R, Albright TD, Gross CG, Bruce C (1984) Stimulus selective properties of inferior temporal neurons in the macaque. $J$ Neurosci 4:2051-2062.

Desimone R, Schein SJ, Moran J, Ungerleider LG (1985) Contour, color, and shape analysis beyond the striate cortex. Vision Res 25 : $441-452$.

Desimone R, Li L, Lehky S, Ungerleider LG, Mishkin M (1990) Effects of $\mathrm{V} 4$ lesions on visual discrimination performance and on responses of neurons in inferior temporal cortex. Soc Neurosci Abstr 16:621.

Desimone R, Moran J, Schein SJ, Mishkin M (1992) A rolc for the corpus callosum in visual area V4 of the macaque. Vis Neurosci 10: 159-171.

DeYoe EA, Sisola LC (1991) Distinct pathways link anatomical subdivisions of $\mathrm{V} 4$ with $\mathrm{V} 2$ and temporal cortex in the macaque monkey. Soc Neurosci Abstr 17:1282.

DeYoe EA, Van Essen DC (1985) Segregation of efferent connections and receptive field properties in visual area V2 of the macaque. Nature 317:58-61.

DeYoe EA, Felleman DJ, Knierim JJ, Olavarria JF, Van Essen DC (1988) Heterogeneous subregions of macaque visual area V4 receive selective projections from $\mathrm{V} 2$ thin stripe and interstripe subregions. Invest Ophthalmol Vis Sci [Suppl] 29:115.

Distler C, Ungerleider LG, Boussaoud D, Desimone R (1991) Cortical connections of temporal-lobe area TEO in macaques. Eur J Ncurosci [Suppl] 4:56.

Distler C, Boussaoud D, Desimone R, Ungerleider LG (1993) Cortical connections of inferior temporal area TEO in macaque monkeys. $J$ Comp Neurol, in press.

Felleman DJ, Van Essen DC (1991) Distributed hierarchical processing in the primate cerebral cortex. Cereb Cortex 1:1-47.

Fenstemaker SB, Olson CR, Gross CG (1984) Afferent connections of macaque visual areas V4 and TEO. Invest Ophthalmol Vis Sci [Suppl] 25:213.

Ferrera VP, Nealey TA, Maunsell JHR (1992) Mixed parvocellular and magnocellular geniculate signals in visual area V4. Nature 358: 756-758.

Fitzpatrick D, Lund JS, Blasdel GG (1985) Intrinsic connections of macaque striate cortex: afferent and efferent conncctions of lamina 4C. J Neurosci 5:3329-3349.

Fujita I, Tanaka K, Ito M, Chang K (1992) Columns for visual features of objects in monkey inferotemporal cortex. Nature 360:343-346.

Gattass R, Gross CG, Sandell JH (1981) Visual topography of V2 in the macaque. J Comp Neurol 201:519-530.

Gattass R, Sousa APB, Gross CG (1988) Visuotopic organization and extent of V3 and V4 of the macaque. J Neurosci 8:1831-1845.

Gattass R, Rosa MGP, Sousa APB, Pinon MCG, Fiorani M Jr, Neuenschwander S (1990) Cortical streams of visual information processing in primates. Braz J Med Biol Res 23:375-393.

Gibson AR, Hansma DI, Houk JC, Robinson FR (1984) A sensitive low artifact TMB procedure for the demonstration of WGA-HRP in the CNS. Brain Res 298:235-241.

Hendrickson AE, Wilson JR, Ogren MP (1978) The neuroanatomical organization of pathways between the dorsal lateral geniculate nucleus and visual cortex in old world and new world primates. J Comp Neurol 182:123-136.

Heywood CA, Cowey A (1987) On the role of cortical area V4 in the discrimination of hue and pattern in macaque monkeys. J Neurosci 7:2601-2617.

Heywood CA, Gadotti A, Cowey A (1992) Cortical area V4 and its role in the perception of color. J Neurosci 12:4056-4065.

Horton JC (1984) Cytochrome oxidase patches: a new cytoarchitectonic feature of macaque visual cortex. Philos Trans $R$ Soc Lond [Biol] 304:199-253.
Horton JC, Hubel DH (1981) Regular patchy distribution of cytochrome oxidase staining in primate visual cortex of macaque monkey. Nature 292:762-764.

Hubel DH, Livingstone MS (1985) Complex-unoriented cells in a subregion of primate area 18 . Nature 315:325-327.

Hubel DH, Livingstone MS (1987) Segregation of form, color, and stcreopsis in primate area 18. J Neurosci 7:3378-3415.

Hubel DH, Wiesel TN (1972) Laminar and columnar distribution of geniculo-cortical fibers in the macaque monkey. J Comp Neurol 146: $421-450$.

Humphrey AL, Hendrickson AE (1983) Background and stimulusinduced patterns of high metabolic activity in the visual cortex (area 17) of the squirrel and macaque monkey. J Neurosci 3:345-358.

Krubitzer L, Kaas J (1990) Convergence of processing channels in the extrastriate cortex of monkeys. Vis Neurosci 5:609-613.

Kuypers HGJM, Szwarcbart MK, Mishkin M, Rosvold HE (1965) Occipitotemporal corticocortical connections in the rhesus monkey. Exp Neurol 11:245-262.

Lachica EA, Beck PD, Casagrande VA (1992) Parallel pathways in macaque monkey striate cortex: anatomically defined columns in laycr III. Proc Natl Acad Sci USA 89:3566-3570.

Lennie P, Krauskopf J, Sclar G (1990) Chromatic mechanisms in striate cortex of macaque. J Neurosci 10:649-669.

Livingstone MS, Hubel DH (1982) Thalamic inputs to cytochrome oxidase-rich regions in monkey visual cortex. Proc Natl Acad Sci USA 79:6098-6101.

Livingstone MS, Hubel DH (1984) Anatomy and physiology of a color system in the primate visual cortex. J Neurosci 4:309-356.

Livingstone MS, Hubel DH (1987) Connections between layer 4B of area 17 and the thick cytochrome oxidase stripes of area 18 in the squirrel monkey. J Neurosci 7:3371-3377.

Lund JS (1973) Organization of neurons in the visual cortex, area 17, of the monkey (Macaca mulatta). J Comp Neurol 147:455-496.

Lund JS, Boothe RG (1975) Intralaminar connections and pyramidal ncuron organization in the visual cortcx, area 17, of the macaque monkey. J Comp Neurol 159:305-334.

Maguire WM, Baizer JS (1984) Visuotopic organization of the prelunate gyrus in rhesus monkey. J Neurosci 4:1690-1704.

Maunsell JHR, Newsome WT (1987) Visual processing in monkey extrastriate cortex. Annu Rev Neurosci 10:363-401.

Mesulam M-M (1978) Tetramethyl benzidine for horseradish peroxidase histochemistry: a non-carcinogenic blue product with superior sensitivity for visualizing neural afferents and efferents. $J$ Histochem Cytochem 26:106-117.

Miller EK, Li L, Desimone R (1993) Activity of neurons in anterior inferior temporal cortex during a short-term memory task. J Neurosci 13:1460-1478.

Mishkin M, Ungerleider LG, Macko KA (1983) Object vision and spatial vision: two cortical pathways. Trends Ncurosci 6:414-417.

Morel A, Bullier J (1990) Anatomical segregation of two cortical visual pathways in the macaque monkey. Vis Neurosci 4:555-578.

Nakamura H, Gattass R, Desimone R, Ungerleider LG (1991) Comparison of inputs from areas $\mathrm{V} 1$ and $\mathrm{V} 2$ to areas $\mathrm{V} 4$ and TEO in macaques. Soc Neurosci Abstr 17:845.

Olavarria J, Van Sluyters RC (1985) Unfolding and flattening the cortex of gyrencephalic brains. J Neurosci Methods 15:191-202.

Rosa MPG, Gattass R, Fiorani M Jr (1988) Complete pattern of ocular dominance stripes in Vl of a new world monkey, Cebus apella. Exp Brain Res 72:645-648.

Rosa MPG, Gattass R, Soares JGM (1991) A quantitative analysis of cytochrome oxidase-rich patches in the primary visual cortex of Cebus monkeys: topographic distribution and effects of late mononucleation. Exp Brain Res 84:195-209.

Rosene DL, Roy NJ, Davis BJ (1986) A cryoprotection method that facilitates cutting frozen sections of whole monkey brains for histological and histochemical processing without freezing artifact. J Histochem Cytochem 34:1301-1315.

Schein SJ, Desimone R (1990) Spectral properties of V4 neurons in the macaque. J Neurosci 10:3369-3389.

Schiller PH, Lee K (1991) The role of the primate extrastriate area $\mathrm{V} 4$ in vision. Science 251:1251-1253.

Shipp S, Zeki S (1985) Segregation of pathways leading from area V2 to areas V4 and V5 of macaque monkey visual cortex. Nature 315 : 322-325. 
Shipp S, Zeki S (1989) The organization of connections between areas V5 and V2 in macaque monkey visual cortex. Eur J Neurosci 1:333354.

Silverman MS, Tootell RBH (1987) Modified technique for cytochrome oxidase histochemistry: increased staining intensity and compatibility with 2-deoxyglucose autoradiography. J Neurosci Methods 19:1-10.

Steele GE, Weller RE, Cusick CG (1991) Cortical connections of the caudal subdivision of the dorsal area (V4) in monkeys. J Comp Neurol 306:495-520.

Tanaka K, Saito H, Fukuda Y, Moriya M (1991) Coding visual images of objects in the inferotemporal cortex of the macaque monkey. J Neurophysiol 66:170-189.

Tanaka M, Lindsley E, Lausmann S, Creutzfeldt OD (1990) Afferent connections of the prelunate visual association cortex (areas V4 and DP). Anat Embryol (Berl) 181:19-30.

Tootell RBH, Silverman MS (1985) Two methods for flat-mounting cortical tissue. J Neurosci Methods 15:177-190.

Tootell RBH, Silverman MS, De Valois RL, Jacobs GH (1983) Functional organization of the second cortical visual area in primates. Science 220:737-739.

Tootell RBH, Silverman MS, Hamilton SL, De Valois RL, Switkes E (1988a) Functional anatomy of macaque striate cortex. III. Color. J Neurosci 8:1569-1593.

Tootell RBH, Hamilton SL, Switkes E (1988b) Functional anatomy of macaque striate cortex. IV. Contrast and magno-parvo streams. J Neurosci 8:1594-1609.

Tootell RBH, Silverman MS, Hamilton SL, Switkes E, De Valois RL (1988c) Functional anatomy of macaque striate cortex. V. Spatial frequency. J Neurosci 8:1610-1624.

Ts'o DY, Gilbert CD (1988) The organization of chromatic and spatial interactions in the primate striate cortex. J Neurosci 8:1712-1727.

Ungerleider LG (1985) The corticocortical pathways for object recognition and spatial perception. In: Pattern recognition mechanisms (Chagas C, Gattass R, Gross CG, eds), pp 21-37. Vatican City: Pontifical Academy of Sciences.

Ungerleider LG, Mishkin M (1982) Two cortical visual systems. In: Analysis of visual behavior (Ingle DJ, Goodale MA, Mansfield RJW, eds), pp 549-586. Cambridge, MA: MIT Press.

Ungerleider LG, Gattass R, Sousa APB, Mishkin M (1983) Projections of area V2 in the macaque. Soc Neurosci Abstr 9:152.

Ungerleider LG, Desimone R, Moran J (1986) Asymmetry of central and peripheral field inputs from area $V 4$ into the temporal and parietal lobes of the macaque. Soc Neurosci Abstr 12:1182.

Van Essen DC, Felleman DJ, DeYoe EA, Olavarria J, Knierim JJ (1991) Modular and hierarchical organization of extrastriate visual cortex in the macaque monkey. Cold Spring Harbor Symp Quant Biol 55:679696.

Van Essen DC, Anderson CH, Felleman DJ (1992) Information pro- cessing in the primate visual system: an integrated systems perspective. Science 255:419-423.

Walsh V, Butler SR, Carden D, Kulikowski JJ (1992a) The effects of V4 lesions on the visual abilities of macaques: shape discrimination. Behav Brain Res 50:115-126.

Walsh V, Kulikowski JJ, Butler SR, Carden D (1992b) The effects of lesions of area V4 on the visual abilities of macaques: colour categorization. Behav Brain Res 52:81-89.

Weller RE (1988) Two cortical visual systems in old world and new world primates. In: Progress in brain research, Vol 75 (Hicks TP, Benedek G, eds), pp 293-306. Amsterdam: Elsevier.

Weller RE, Kaas JH (1985) Cortical projections of the dorsolateral visual area in owl monkeys: the prestriate relay to inferior temporal cortex. J Comp Neurol 234:35-59.

Weller RE, Kaas JH (1987) Subdivisions and connections of inferior temporal cortex in owl monkeys. J Comp Neurol 256:137-172.

Weller RE, Steele GE (1992) Cortical connections of subdivisions of inferior temporal cortex in squirrel monkeys. J Comp Neurol 324: 37-66.

Wild HM, Butler SR, Carden D, Kulikowski JJ (1985) Primate cortical area V4 important for colour constancy but not for wavelength discrimination. Nature 313:133-135.

Wong-Riley MTT, Carroll EW (1984) Quantitative light and electron microscopic analysis of cytochrome oxidase-rich zones in V II prestriate cortex of the squirrel monkey. J Comp Neurol 222:18-37.

Yoshioka T, Levitt JB, Lund JS (1992) Intrinsic lattice connections of macaque monkey visual cortical area V4. J Neurosci 12:27852802.

Yukie M, Iwai E (1985) Laminar origin of direct projection from cortex area V1 to V4 in the rhesus monkey. Brain Res 346:383-386.

Zeki SM (1973) Colour coding in rhesus monkey prestriate cortex. Brain Res 53:422-427.

Zeki SM (1978a) The cortical projections of foveal striate cortex in the rhesus monkey. J Physiol (Lond) 277:227-244.

Zeki SM (1978b) Functional specialisation in the visual cortex of the rhesus monkey. Nature 274:423-428.

Zeki SM (1978c) Uniformity and diversity of structure and function in rhesus monkey prestriate visual cortex. J Physiol (Lond) 277:273290.

Zeki SM (1983a) The distribution of wavelength and orientation selective cells in different areas of monkey visual cortex. Proc R Soc Lond [Biol] 217:449-470.

Zeki SM (1983b) Colour coding in the cerebral cortex: the reaction of cells in monkey visual cortex to wavelength and colours. Neuroscience 9:741-765.

Zeki S, Shipp S (1988) The functional logic of cortical connections. Nature 355:311-317.

Zeki SM, Shipp S (1989) Modular connections between areas V2 and V4 of macaque monkey visual cortex. Eur J Neurosci 1:494-506. 